\title{
Private Demand Weakens
}

\begin{abstract}
A gGregate DeMAND has continued to increase in recent months but less rapidly than in 1965 and early 1966. Prices have risen more slowly, and interest rates have declined. Economic stabilization policy continues to combine an expansionary fiscal situation and restrictive monetary developments.
\end{abstract}

\section{Aggregate Demand}

Growth in aggregate demand has slowed from the rapid pace of 1965 and early 1966. Retail sales, a major component of total demand, have increased little since midsummer, after rising about 8 per cent during the year ended in June. Reduced automobile sales have been a major factor in the slower growth of total retail sales. Personal income, however, has continued to grow at about an 8 per cent annual rate.

Slackening in demand may also be reflected in the relation of business inventories to sales. By October 1966 inventories had risen to 1.52 times the volume of sales. From 1961 to early 1966 inventories trended downward from about 1.60 times sales to about 1.43 .

During periods of rapid growth in demand for goods and services, inventories do not usually keep pace with sales. Subsequently, when sales begin to slow, firms usually do not adjust inventory accum-

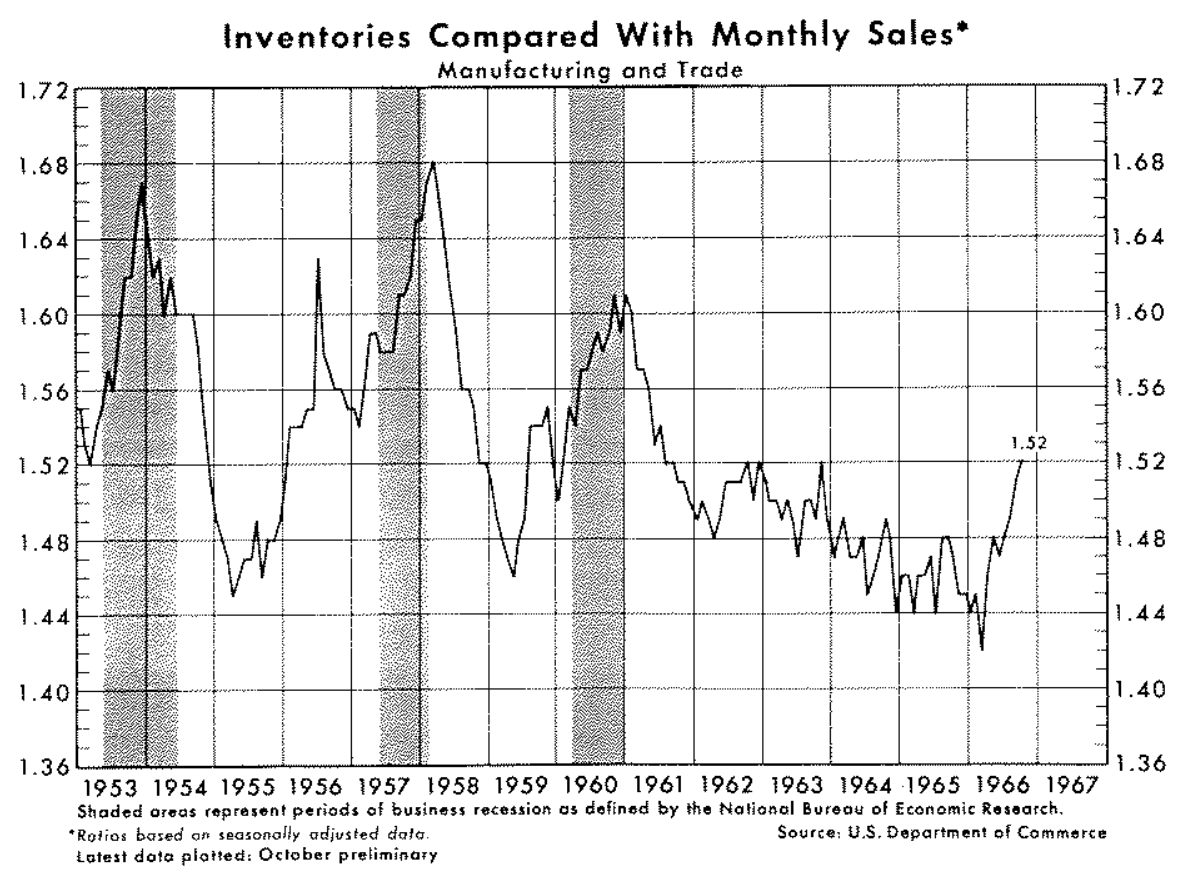

ulation immediately with the result that inventories tend to increase relative to sales. The ratio of inventories to sales in October was about 3.5 per cent above the trend relationship, roughly the same level as has frequently occurred around peaks in business activity.

An impetus to inventory accumulation is provided by rising prices if firms attempt to hedge against the possibility of future price increases and shortages. Relatively high interest costs are nomally less of a deterrent to inventory accumulation if debt repayment is expected to be made in cheaper dollars.

\section{Real Output and Prices}

Output has recently increased at a reduced pace. Industrial production rose at a 1 per cent annual rate from August to November after advancing at a 7 per cent rate from March to August and 9 per cent during the year ended last March. Total production measured in constant dollars grew at a 3 per cent rate from the first to the third quarter of 1966 compared with a 7 per cent rate from late 1964 to early 1966 . The decline in the rate of increase of real product reflects problems of resource bottlenecks resulting from nearcapacity utilization in some areas, and problems of redirecting resources to the production of military goods, as well as a reduced rate of increase in total demand.

Upward pressures on prices appear to have moderated, reflecting less rapid growth in total demand. Consumer prices increased at a 2.8 per cent annual rate from August to November compared with a 3.7 per cent rate from October 1965 to August. General wholesale prices have declined since August compared with an increase at a 4.3 per cent rate from October 1965 to August. The recent decline in these prices is a reflection of price decreases in farm products and processed foods accompanied by only slight rises in industrial prices. 


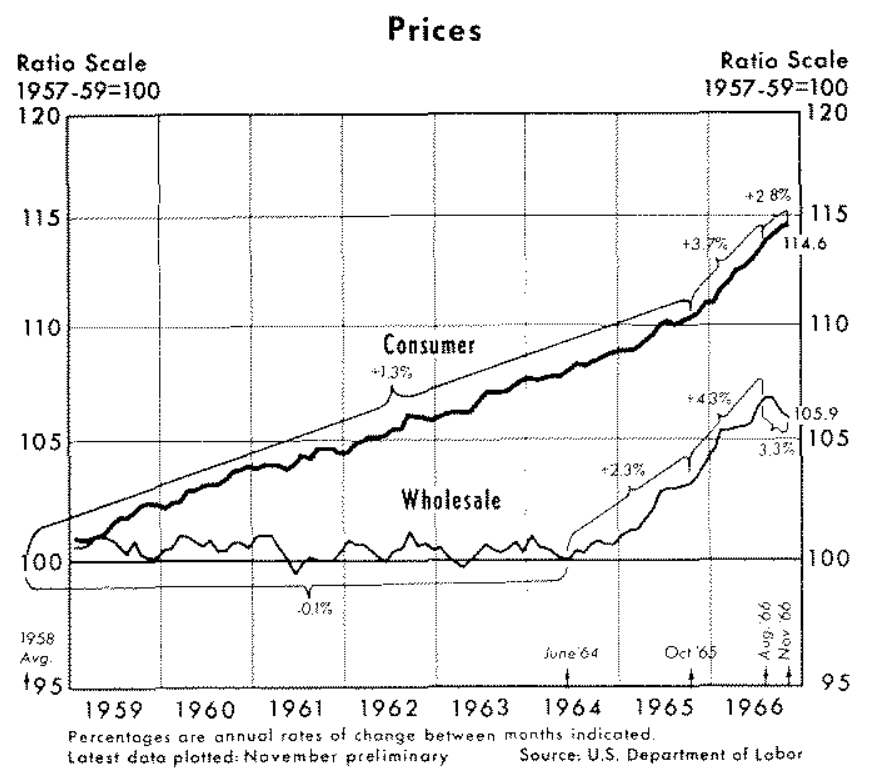

\section{Fiscal Developments}

The Federal Government has continued to provide a major stimulus to economic activity primarily as a result of the large defense expenditures for the Vietnam conflict. On a national accounts basis adjusted for cyclical variation in economic activity, the so-called high-employment budget, the Federal Government ran a $\$ 1$ billion surplus during the year ended in the third quarter compared with about an $\$ 8$ billion average surplus from 1961 to 1965 . It is estimated that in the fourth quarter of 1966 this budget measure showed a $\$ 1.5$ billion deficit. The lower this measure, the more stimulative the budget, according to a view expressed in several annual reports of the Council of Economic Advisers.

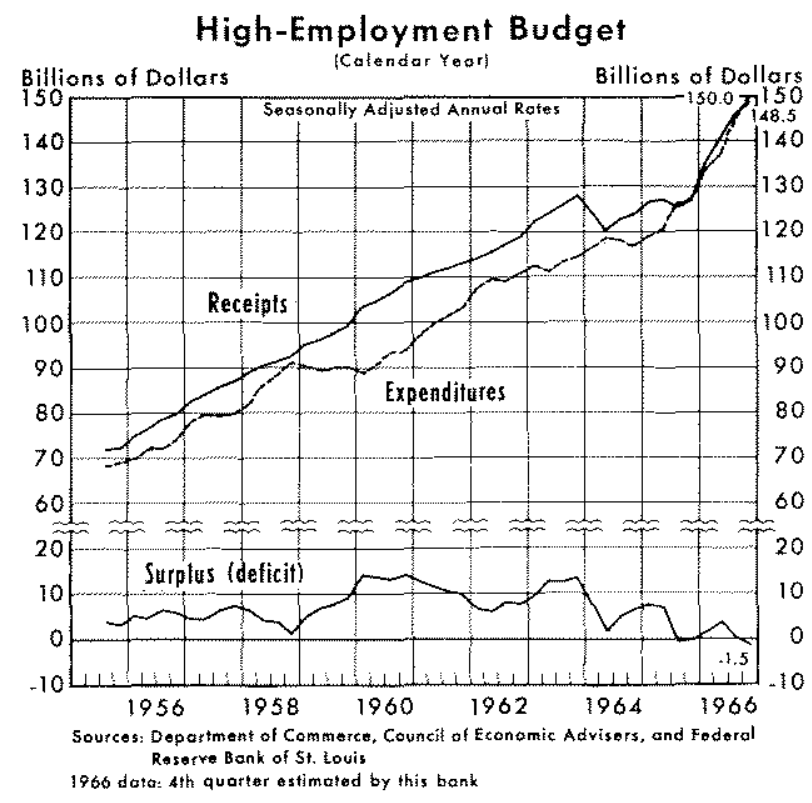

From the first to the third quarter of 1966 an increase in defense expenditures accounted for about 30 per cent of the rise in GNP compared with 2 per cent in the previous three years. These data indicate that a sizable shift of resources from the production of civilian goods and services to military goods and services took place in 1966. The current and immediately prospective changes in Federal Government expenditures will be crucial to the future course of the economy.

\section{Monetary and Financial Developments}

Beginning in the spring of 1966 monetary develop. ments provided some offset to the expansionary or inflationary effects of the Federal budget. Since spring the nation's money stock has declined at about a 0.5 per cent annual rate compared with an increase of 6 per cent during the previous 12 months.

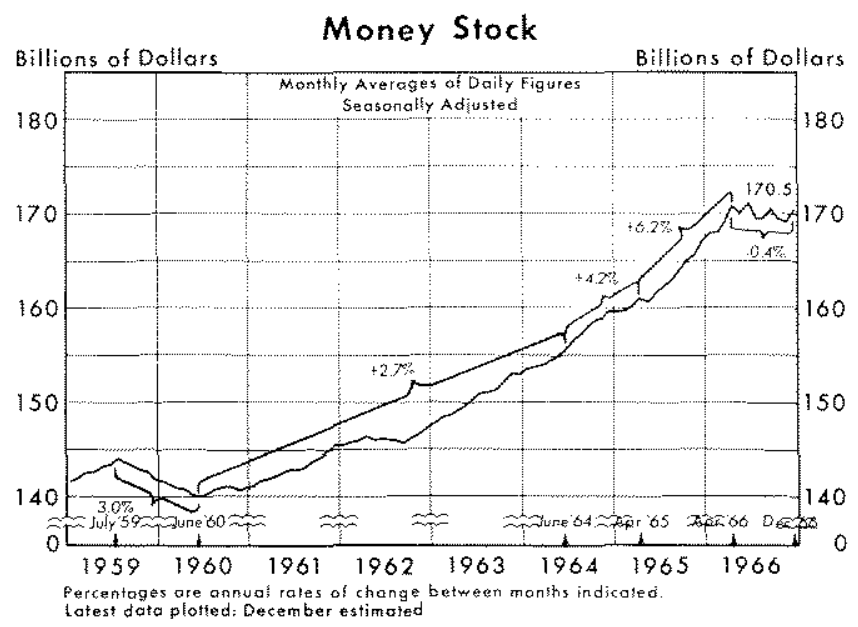

This decline in money reflected a substantial reduction of member bank reserves available for private demand deposits. Since spring these reserves, adjusted for changes in reserve requirements, have declined at a 2 per cent annual rate compared with an increase of 5 per cent during the year ended in April. Total reserves of member banks have followed a similar course. Since spring these reserves, adjusted for changes in reserve requirements, have declined at an annual rate of 2.7 per cent compared with a 5 per cent increase during the preceding 12 months.

These abrupt changes in the course of reserves reflected a marked change in the rate of expansion of Federal Reserve credit, particularly a much slower rate of Federal Reserve net purchase of securities. Since late August this credit has remained about unchanged. Since spring it has increased at an annual rate of about 3 per cent compared with 8 per cent during the previous year. 
Reserves of Member Banks

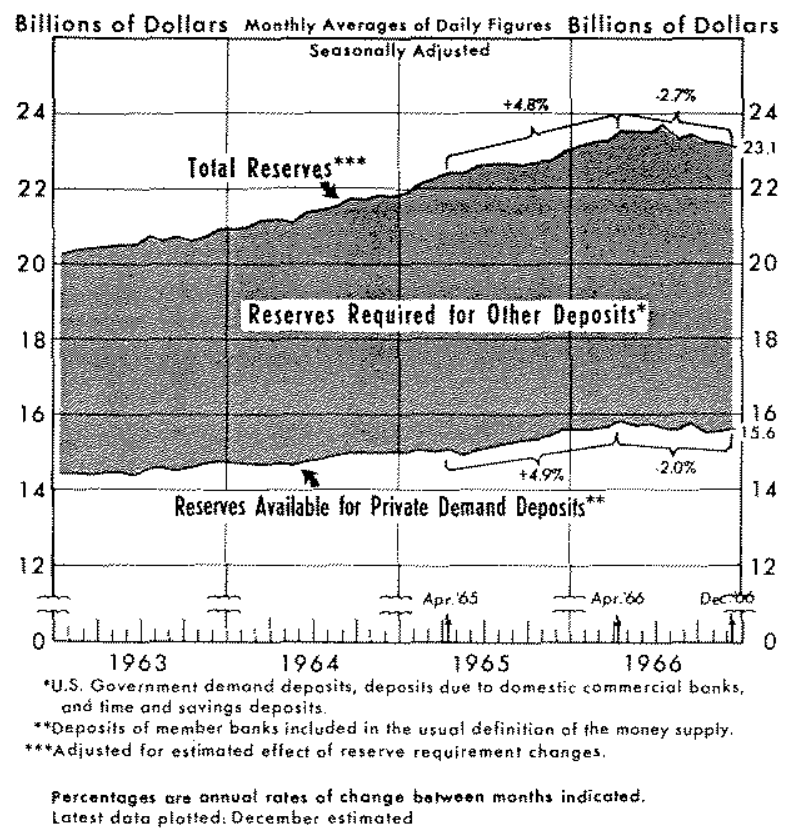

Total bank credit (loans and investments) declined at an estimated 1.2 per cent annual rate from August to December after increasing 9 per cent during the previous 12 months. The decline after August reflected slower growth of total loans and other securities and accelerated liquidation of Government securities.

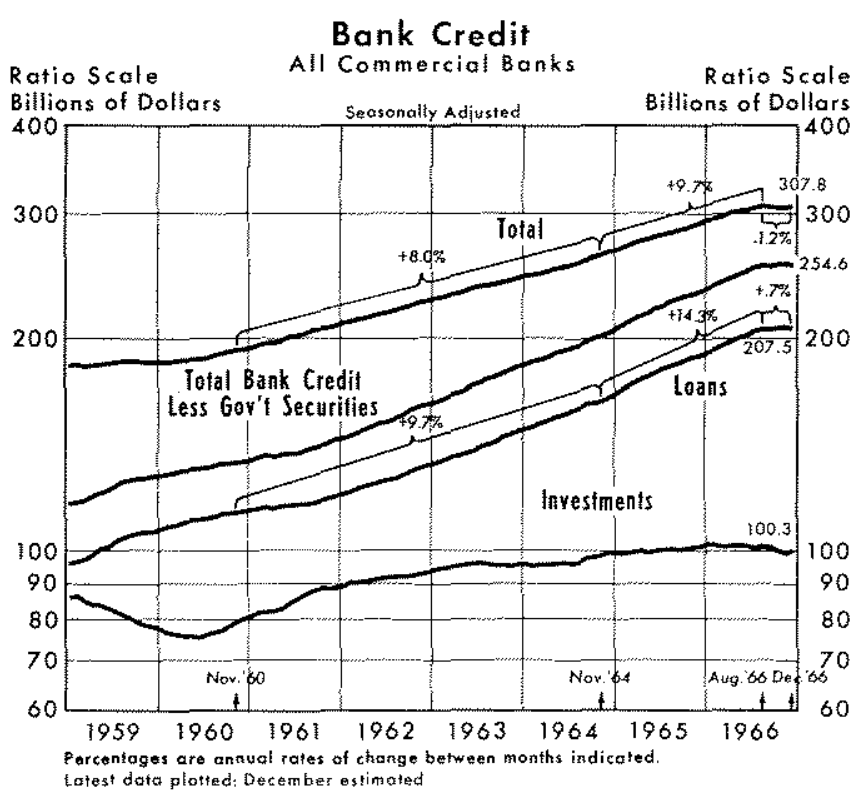

\section{Interest Rates and Time Deposits}

Interest rates have declined since mid-September after increasing rapidly during the summer. These
SELECTED INTEREST RATES

\begin{tabular}{|c|c|c|}
\hline & $\begin{array}{c}\text { Seplember } \\
1966\end{array}$ & $\begin{array}{c}\text { Lotest } \\
\text { Avallable }\end{array}$ \\
\hline Prime bankers' acceplances ....... & $5.75 \%$ & $5.50 \%$ \\
\hline 3-month Treasury bills $\ldots \ldots \ldots \ldots$. & 5.36 & 4.80 \\
\hline tong-term Government bonds . . . . . & 4.79 & 4.54 \\
\hline State and local Aca bonds ....... & 3.93 & 3.74 \\
\hline Corporate Aco bonds ............. & 5.49 & 5.43 \\
\hline
\end{tabular}

recent declines may represent in part reduced demands for credit by business and individuals for the Federal Govermment borrowed heavily.

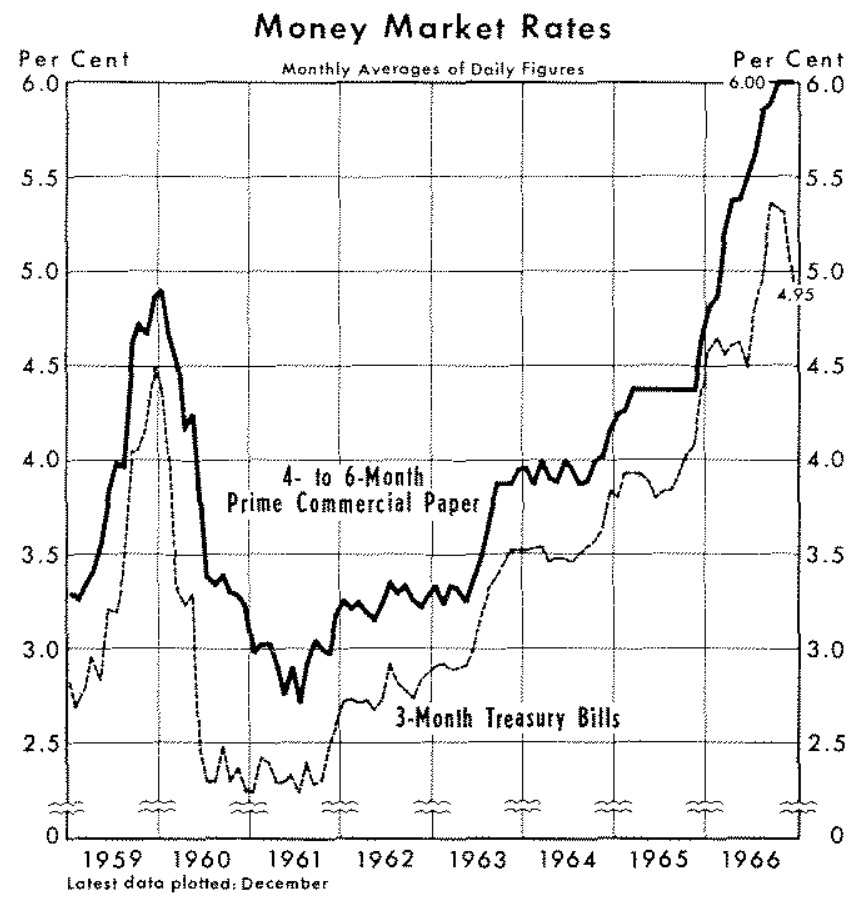

Some short-term market interest rates, through midDecember, remained above the 5.5 per cent maximum rate which commercial banks can pay on certificates of deposit (CD's) over $\$ 100,000$. For example, the prime 4- to 6-month commercial paper rate stood at 6 per cent, a half percentage point above the max imum $C D$ rate. This continuing differential limited the growth of time deposits. From mid-August to early December time deposits at all commercial banks changed little, remaining at about $\$ 157$ billion compared with a 12 per cent increase during the 12 months ended in August. Large CD's, a component of time deposits, declined sharply from late Augnst to midDecember. Since these deposits are especially sensitive to interest rate differentials, they might reverse their recent decline and rise markedly if short-term market rates were to decline further. 